\title{
Sustainable/ Green Product Packaging From the Shoppers Perspective: A Case of Saudi Arabia
}

\author{
Salah Abunar $^{1} \&$ Mohammad Zulfeequar Alam ${ }^{1}$ \\ ${ }^{1}$ University of Business \& Technology (UBT), Jeddah, Saudi Arabia \\ Correspondence: Dr. Mohammad Zulfeequar Alam, Associate Professor of Marketing, Department of Marketing, \\ College of Business Administration (CBA), University of Business \& Technology (UBT), P.O. Box 110200, Jeddah \\ 21361, Saudi Arabia.
}

Received: June 25, 2020

Accepted: July 30, 2020

Online Published: September 3, 2020

doi:10.5430/rwe.v11n5p164

URL: https://doi.org/10.5430/rwe.v11n5p164

\begin{abstract}
Background/Objectives: Global warming, contamination and climate change are some of the problems that have become an increasingly concerning issue internationally. Buyers' concerns about environmental protection have led to the diversification in consumer buying approach towards a green lifestyle. Therefore, firms are taking action to develop potential ecological strategies in the green market industry. This paper aims to explore and determine the insight of Saudi shoppers regarding sustainable (Green) product packaging to maintain a sustainable and green environment.

Material and methods: A sample survey of 232 consumers of Saudi Arabia. Descriptive statistical tools were used, for hypothesis testing, Chi-square test/ Chi-Square Goodness of fit test was applied at Alpha 0.05 with $95 \%$ of confidence level.

Findings: The result conveys that the knowledge and information towards green product packaging are not favorable, the product labels as a source of information for sustainable packaging considered the primary source for the green product.

Conclusion: The marketers, and stakeholders having environmental concern, need to have a great call to the campaign of sustainable/ green product packaging. Besides, it is recommended that the marketer of an eco-friendly product need to consider product labels as a good source of information for sustainable packaging at a priority level.

Significance of the study: This research will contribute to the related stakeholders to realize the insight of sustainable (green) products packaging. Besides, it will give a better understanding of consumers' behavior regarding sustainable/ green packaging that will lead to achieving their goals in a suitable approach.
\end{abstract}

Keywords: green marketing, sustainability, sustainable packaging, green product, green consumer, Saudi Arabia

\section{Introduction}

Nowadays, the environment has shifted a mainstream issue in the current competitive world. Green marketing has a significant trend to investigate the reason for global warming, ozone depletion, pollution, loss of biodiversity and deforestation. The American Marketing Association (AMA) defines sustainable or green marketing as the marketing of products that are believed to be environment-friendly, which organizes into different activities such as product adjustment, modification of production processes, packaging, labelling, advertising strategies as well as increases awareness on compliance marketing amongst industries (Yazdanifard \& Mercy, 2011). However, because of the new directions for environmental protection, it not only has to protect the products but must also be environmentally friendly. Today, packaging must meet both essential product requirements and specific environmental objectives. The packaging has four different marketing functions. First, it contains and protects the product; second, the packaging's role is to promote the product. It also helps consumers to use the product and, lastly, packaging facilitates recycling and decrease environmental damage (Lamb et al., 2011). Carlson considers that eco-packaging must have benefits for the consumer, be safe and healthy for the individual and the community throughout its life cycle, be market-efficient and cost-effective; be obtained, produced, transported, and recycled via sources of renewable energy, as well as maximizing the use of renewable or recyclable materials; utilize clean production technologies and best practices; can be designed to optimize the materials and energy used, and can be effectively recovered and reused in numerous production cycles (Carlson, 2009) . Moreover, green packaging is defined by Diglel, and Yazdanifard (2014) 
packaging is one of the marketing elements and among one of the activities, which has alteration of the progression in packaging. As buyers are becoming more attentive towards their environmental approaches, desires, and purchases, this has led to the increased motive of consumers to purchase environmentally friendly products and services. Due to the increase in the campaign, now the consumer is more concern about environmental issues and hence will consider purchasing products that are more environmentally friendly, even if these products are charged at higher prices. From the above aspects, it was felt that there is a need to do a study from the packaging points of view. It has been noticed that there are various studies has been done on sustainable/ green environment. However, very few studies concerned the study related to the shopper awareness towards green product packaging in general and especially in the case of the Saudi Arabian context. Consequently, the main objective of this research is to determine the perspicacity of the Saudi consumer regarding the role of sustainable (Green) product packaging that will help in the formation of sustainable behavior in the region and consequently, the following specific research objectives have been considered for the current study:

1. To explore the knowledge and information of Saudi Arabian consumer regarding the green packaging of the product

2. To analyze the information sources about the ecological (Organic) Product packaging

3. To understand the factors of willingness to pay for the ecological/ Organic

4. To assess the factors of unwillingness to purchase for the ecological/ organic packaging product

5. To examine the Consumer attitudes towards consideration of quality certification (stamp) on the packaging before the purchase of an organic product such as The Saudi standards metrology and quality Organization (SASO) / Saudi food and drug authority (SFDA)

6. To identify the views of the consumer regarding the responsibility towards a sustainable environment

\section{Significance of the Study}

This research will help to the related stakeholders to know the insight of purchaser about sustainable/ ecological (green) products packaging. Besides, it will give a better understanding of consumers' behavior regarding sustainable/ green packaging that will lead to achieving more market in applicable approach. Also, it will support to maintain and lead the competitive market. Lastly, it will facilitate to understand the consumer attitude towards the sustainable environment in general and particularly to the packaging of products, and overall proper guidelines and policy can be made by the marketer as well as a related stakeholder who has concerned to the sustainable/green environment.

\section{Literature Review}

In recent years, the need for green purchasing has heightened, and environmental issues in the world have become more noticeable. The term "green packaging" is used interchangeably with "sustainable packaging", "ecological packaging", green packaging or "environmental packaging (Stern \& Ander, 2008). The packaging is one of the most valuable constituents of the food product or non-food product because a well-packed product can be a guarantee of consumer protection. The investment in packaging is a communication instrument between businesses and final consumers, and it is capable of attracting consumer's attention (Draskovic et al., 2009). Consequently, these vital environmental issues combined with the demand by consumer groups for sustainable/ green products have led to the emergence of green packaging. Green packaging relates to business practice which advocates sustainable development. It comprises the packaging of goods and services that are eco-friendly and promoting the preservation of the environment sustainably. Moreover, green packaging has become an essential area of focus for both companies and society usually (Ansar, 2013). In general, the main objectives of green packaging are to reduce the environmental uncertainties which are caused by the manufacturing and to extend corporate eco-centric image in the consumers' perception (Yazdanifard \& Mercy, 2011). In addition, today, packaging demand to meet both essential product requirements and specific environmental objectives. The packaging has four different marketing functions. First, it contains and protects the product; second, the packaging's role is to promote the product. It also helps consumers to use the product and, lastly, packaging facilitates recycling and decrease environmental damage (Alam, 2020).

\subsection{Consumers Awareness Towards Green Products}

Sustainable development was defined as 'meets the needs of the present without compromising the ability of future generations to meet their own needs' by the Brundtland (Brundtland, 1987). According to the investigation due to deficiency of information, most customers are not exactly aware of the significance of green product (Arseculeratne \& Yazdanifard, 2014). In another research, it has been noted that most of the consumers were unaware of severe environmental issues, and it affects the use of the product (Golkonda, 2013). It was also revealed that women consumer 
was significantly more leading than men consumer in having sufficient information regarding organic packaging (Anvar \& Venter, 2014). In a further study it has been recognized by the previous researcher that women consumer was more informed and concerned about environmental issues than men consumer (Suki, 2013). A study also described that consumers' response to environmentally active regarding green food packaging were not well understood with concerning the consumer purchasing behavior (Ketelsen et al., 2020).

\subsection{Consumer Knowledge Source Towards Sustainable (Green) Products}

One of the essential elements of green product development is the promotion of eco-labels on the products (Yeow Kar Yan \& Rashad Yazdanifard 2014). Eco-labelling is a useful tool which can provide the information on two main functions which is the information function that addresses the quality characteristics of the tangible product and the value function which provides the corporate environmental image of the firm (Sammer \& Wüstenhagen, 2006). In the eyes of consumers, eco-label/ green label is an innovation. In a study, it is revealed that the information on the product has to be reliable and it was also indicated that labels provide practical instructions and meaning to consumers as it addresses a vital role in consumers' purchasing decision (Pedersen \& Neergaard, 2006). Rashid (2009) observed that the consumers who have environmental knowledge enable them to differentiate the products which are more environmentally preferable in the marketplace; thus, eco/ green-labels were initiated to promote environmental consumerism.

The study done by Prohit (2012), showed that green product label creates a distinct image to the consumers' cognition, and the positioning of a product make up the consumers' first choice of purchase (Prohit, 2012). Corresponding to the study, it was also explored that environmental knowledge of young consumers affects their environmental attitude, and it also shows that environmental attitudes of young consumers affect their green product purchasing behavior (Fatah Uddin \& Mohammed, 2018). Moreover, a study done by Prohit (2012) the credible environmental information positively influences the consumers' purchase intention toward a brand, and it will increase the sales volume of the firm (Prohit, 2012).

\subsection{Consumer Perception Towards Price of Green Products}

Price relates to the value an individual must pay to obtain an item (Burrow, 2008). It is a crucial element of the green marketing mix that presumes price to be the main reason not to buy green products as they consider them to be expensive as perceived by the consumer (Bukhari, 2011). A report reveals that product characteristics such as price and product quality are more relevant to consumers than the environmentally friendly packaging product (Ketelsen et al., 2020). In Nielsen global survey of sixty countries has expressed that $55 \%$ of global online consumers across the countries were willing to pay more for products and services to the companies that were dedicated to the positive social and environmental impact on society (Rayapura, 2014). Here it is refreshing to note that this study does not support the previous study (Suki, 2013). As revealed by Boztepe (2012) in his study, he found a noticeable shift in the relationship between price and consumer purchasing behavior, as young consumers showed a willingness to pay the price for eco-friendly products, in comparison to previous studies (Tina et al., 2010).

Moreover, in a study done by Chen (2010) it was affirmed that the consumers who are willing to pay the premium price being proactive in its attitude towards pollution issues. Besides, the consumers express a positive attitude towards green products, and this will bring a positive effect to the brand equity. It has increased the possibility for company lead in the future if adopting green product packaging (Chen, 2010).

\subsection{Social Responsibility Towards Sustainable/ Green Products Packaging}

In a research done by Polonsky (1994) it was indicated that the firms performed with the guidelines which describe the environmental benefits, providing environmental criteria, explaining the way the environmental benefits has achieved in developing the comparative advantages, avoiding the dangerous content and expressing the environmental claims in picture or text were positively impacted to their business (Polonsky, 1994). The companies having environmental concerns are connected to the benefit towards the green environment and their issues connected to the consumer and the surroundings. It was also noted that initially, the user plays an essential role in consumerism and environmental consciousness (Kaufmann et al., 2012). Many marketers may choose to enhance the consumers' consciousness of environmental problems by using marketing ploys to get them involved in social welfares which motivate the consumers to move from conventional products to eco-friendly products (Golkonda, 2013).

\subsection{Sustainable (Green) Products Packaging in Saudi Arabia}

Sustainable (green) development has been a frequently essential dimension in the Kingdom of Saudi Arabia since the beginning of the country's development process, with major highlights of this dimension already evident in Saudi Arabia's long-term strategic directions. Practical implementation of this endeavors proceeded throughout the 
Kingdom's successive five-year development plans that were initiated in 1970, with a primary focus on the development of abilities of citizens, an accomplishment of their purposes, meeting their needs and gaining their standard of living, since citizens are the ultimate target of sustainable development (www.alriyadhdaily.com/article/e094bc6f052f47de859d5c87170dda0) Saudi Arabia is committed to accomplishing sustainable (Green) development. The Kingdom's Vision 2030 plans fall in line with the economic, social, and environmental dimensions of sustainable development (www.arabnews.com/node/1528436/saudi-arabia). Besides that, Saudi Arabia has performed exceptional socio-economic growth over the last four decades. Gross Domestic Product (GDP) increased by 89 per cent from SR1,333 billion in 1980 to SR2,520 billion in 2015 in the 2010 constant prices. In the last 15 years, the GDP growth averaged 4.25 per cent for the period 2008-2015, and the GDP per capita now stands at \$24,507(MOEP). Overall, the 2030 Agenda for Sustainable Development and the Sustainable Development Goals that was adopted at the UN General Assembly in September 2015, is complementary to the achievement of Saudi Vision 2030 (www.alriyadhdaily.com/article/e094bc6f052f47de859d5c87170dda0). Saudi Arabia is one of the biggest markets for the packaging enterprise in the Middle Eastern region (https://www.unicef.org/about/execboard/files/Saudi_Arabia_-_UNCCSF_2017-2021.pdf). The Saudi Arabian plastic packaging market has been estimated at USD 7.64 billion in 2018, and it is forecasted to reach USD 10.64 billion by 2024, registering a CAGR of $5.6 \%$ from 2019 to 2024 (https://www.businesswire.com/news/home/20191106005961/en/Saudi-). Moreover, increasing flexible plastic packaging solutions demand across the end-user industry is driving the market to grow. In the year 2019, the Saudi government introduced a 17\% increase, an estimated USD 45.86 billion, in the funds allocated for healthcare and social development. Out of these allocated funds, approximately USD 12.72 billion has been earmarked for being spent on healthcare projects, directly linked to Saudi Arabia's Vision 2030. Furthermore, the developments in the markets for healthcare, pharmaceuticals, and cosmetics were expected to remain the primary drivers of the demand for plastic packaging products (www.businesswire.com/news/home/20191106005961/en/Saudi-Arabia-Plastic-Packaging-Market-Growth-Trends).

\section{Hypothesis}

The following hypotheses have been undertaken for the study:

Ho1: There are no differences in having sufficient knowledge and information among the consumers regarding the green packaging

Ha2: Women are significantly leading than men in having sufficient information regarding the organic packaging

Ho3: There are no differences among consumers perception regarding the information sources about the ecological (Organic) Product packaging

Ha4: Product labels are the most preferred source of information about ecological (organic) product packaging and the sources

Ho5: There are no differences in the factors of willingness to pay for the ecological/ organic

Ho6: There are no differences among the factors of unwillingness to purchase for the ecological/ organic packaging product

Ha7: Lack of information was the main reason among the factors in the unwillingness to purchase for the ecological/ organic packaging product.

\section{Research Methodology}

The purpose of this study is to investigate the sustainable/ green product packaging from the Shoppers Perspective in Saudi Arabia. To achieve it the target population for this research the consumer of Saudi Arabia was selected. The sample comprised 232 respondents using convenience sampling; this was done with a view to cost and time savings. This study was conducted for a period of four months, from February 202 to May 2020. In this study, the researcher applies a quantitative approach using an exploratory, and descriptive research design using a questionnaire with close-ended questions because it can save respondents' time and effort when answering it. The pilot test was taken among a group of 10 respondents; few minor changes were involved in the questionnaire before the final survey. The data were analyzed with the excel program and social science statistics online program. The descriptive statistical tools were used, for hypothesis testing, Chi-square test/ Chi-Square Goodness of fit test was applied at Alpha 0.05 with $95 \%$ of confidence level. 


\section{Result Findings and Discussion}

Table 1. The demographic profile of respondents

\begin{tabular}{llllll}
\hline $\begin{array}{l}\text { Age groups (in } \\
\text { Years) }\end{array}$ & Frequency & Per cent & Gender & Frequency & Per cent \\
\hline $18-25$ & 20 & 8.621 & Female & 75 & 32.328 \\
\hline $26-35$ & 114 & 49.138 & Male & 157 & 67.672 \\
\hline $36-45$ & 56 & 24.138 & Total & 232 & 100 \\
\hline $46-55$ & 26 & 11.207 & $\begin{array}{l}\text { Monthly income (in } \\
\text { Saudi Riyal) }\end{array}$ & Frequency & Percent \\
\hline $56-65$ & 8 & 3.448 & Below 5000 & 27 & 11.638 \\
\hline 66 and above & 8 & 3.448 & $5000-10000$ & 70 & 30.172 \\
\hline Total & 232 & 100 & $11000-15000$ & 49 & 21.121 \\
\hline Education & Frequency & Percent & $16000-20000$ & 43 & 18.534 \\
\hline Unschooled & 4 & 1.724 & $21000-25000$ & 16 & 6.897 \\
\hline High school & 6 & 2.586 & 26000 and above & 27 & 11.638 \\
\hline Undergraduate & 34 & 14.655 & Total & 232 & 100 \\
\hline Graduate and More & 188 & 81.034 & & & \\
\hline Total & 232 & 100 & & & \\
\hline
\end{tabular}

Source: author's calculations

Table 1 presents the different frequency and percentages of the demographic profile of respondents. Most of the respondents were males $(67.67 \%$ ), while females were $32.33 \%$. It is observed that respondents were mostly in the age groups $26-35$ years old (59.3\%), followed by the age group 36-45 (24.138\%), 46-55 (11.207\%), 18-25 (8.621\% ) and $56-65$ and 66 and above were 3.448 each respectively. This age group of data reveal that majority of respondents belong to young age, it is the age when the people are highly concerned about anything and new to the society and reacts to different situation faster than any other age class. So, this study considers the maximum number of participants from this group. This also represents the status of Saudi Arabian generation nowadays as the majority of Saudi Arabian people belong to this age group. These young people tend to have been more concerned about the green environment and influenced a purchasing decision. With regards to educational qualification, $81.034 \%$ of respondents were graduate and above because the majority of respondents are in this survey are engaged in the academic profession, $14.65 \%$ of respondents were undergraduate, and the rest $4.30 \%$ were high school certified and below. Regarding the income level of respondents the table represent that majority were between 5000 SR to 10,000 SR $(30.172 \%)$, the second-highest of respondents were in the group income level 16,000-20,000 (18.534\%), the income group $26000-25000$ \& Below 5000 were (11.638\% each), and $21000-25000$ SR were $6.897 \%$ ) respectively. There were 232 respondents of the questionnaire in total, and all indicated their demographics here the gender-wise majority of them were male $(67.672 .5 \%)$ and Female was $32.328 \%$ of the total respondents.

Table 2. Consumer perceptions regarding the green product packaging knowledge/information

\begin{tabular}{|c|c|c|c|c|c|c|c|c|}
\hline \multirow[t]{2}{*}{ Variables } & \multirow[t]{2}{*}{ Level } & \multirow[t]{2}{*}{ Counts } & \multirow[t]{2}{*}{ Total } & \multirow[t]{2}{*}{ Per cent } & \multirow[t]{2}{*}{ Proportion } & \multirow[t]{2}{*}{$\mathrm{p}$} & \multicolumn{2}{|c|}{$\begin{array}{l}95 \% \text { CI for } \\
\text { Proportion }\end{array}$} \\
\hline & & & & & & & Lower & Upper \\
\hline \multirow{2}{*}{$\begin{array}{l}\text { In your opinion you have } \\
\text { Sufficient knowledge/ } \\
\text { information on the green } \\
\text { product packaging }\end{array}$} & No & 118 & 232 & 50.86 & 0.509 & 0.844 & 0.442 & 0.575 \\
\hline & Yes & 114 & 232 & 49.14 & 0.491 & 0.844 & 0.425 & 0.558 \\
\hline Total & & 232 & & 100 & 1.00 & & & \\
\hline
\end{tabular}

Note. Proportions tested against a value: 0.5.

Source: author's calculations 
Table 3. Consumer perceptions regarding the green product packaging knowledge/information gender wise

\begin{tabular}{|c|c|c|c|c|}
\hline \multirow[t]{2}{*}{ Variables } & & \multicolumn{3}{|l|}{ Gender } \\
\hline & & Female & Male & Total \\
\hline \multirow[t]{5}{*}{ No } & Count & 33 & 85 & 118 \\
\hline & Expected count & 38.147 & 79.853 & 118 \\
\hline & $\%$ within row & $27.966 \%$ & $72.034 \%$ & $100.000 \%$ \\
\hline & $\%$ within column & $44.000 \%$ & $54.140 \%$ & $50.862 \%$ \\
\hline & $\%$ of total & $14.224 \%$ & $36.638 \%$ & $50.862 \%$ \\
\hline \multirow[t]{5}{*}{ Yes } & Count & 42 & 72 & 114 \\
\hline & Expected count & 36.853 & 77.147 & 114 \\
\hline & $\%$ within row & $36.842 \%$ & $63.158 \%$ & $100.000 \%$ \\
\hline & $\%$ within column & $56.000 \%$ & $45.860 \%$ & $49.138 \%$ \\
\hline & $\%$ of total & $18.103 \%$ & $31.034 \%$ & $49.138 \%$ \\
\hline \multirow[t]{5}{*}{ Total } & Count & 75 & 157 & 232 \\
\hline & Expected count & 75 & 157 & 232 \\
\hline & $\%$ within row & $32.328 \%$ & $67.672 \%$ & $100.000 \%$ \\
\hline & $\%$ within column & $100.000 \%$ & $100.000 \%$ & $100.000 \%$ \\
\hline & $\%$ of total & $32.328 \%$ & $67.672 \%$ & $100.000 \%$ \\
\hline \multicolumn{5}{|c|}{ Chi-Squared Tests } \\
\hline & Value & df & $\mathrm{p}$ & \\
\hline $\mathrm{X}^{2}$ & 2.088 & 1 & 0.148 & \\
\hline $\mathrm{N}$ & 232 & & & \\
\hline
\end{tabular}

Source: author's calculations

Table 2 reveals a total picture of consumer perceptions regarding the green product packaging knowledge/information, by expressing respondents' opinion can be seen as there is not a big difference on the knowledge/ information on the packaging of the green product. Around $51 \%$ respond ace opined that they do not have sufficient knowledge regarding the green (organic) product packaging, and the rest $49 \%$ stated that they have sufficient information regarding it. The Hypothesis (Ho1); There are no differences in having sufficient knowledge and information among the consumers regarding the green packaging has been accepted as the probability of this with a binomial test is equal. The calculated $\mathrm{P}$ is 0.844 for both level; the result is showing higher value than alpha value that was set at $\mathrm{p} 0.05$. Hence it is proved that the hypothesis has been accepted and it can be concluded that there are no differences in the opinion among the consumer towards sufficient knowledge/ information on the green product packaging. Here it is noted that this result also supports the studies done past [15 and 16]. Looking to the hypothesis, Ha2: Women are significantly leading than men in having the sufficient information/ knowledge regarding the organic packaging. From Table 3, it can be seen in that male is having highest knowledge 63.158\% compared to the Female (36.842\%). Although from the Chi-Squared calculated P-value (0.148) is higher than the Alfa value (0.05), and it indicates that there are no differences in opinion gender-wise and variables are independent and insignificance to each other. Therefore, the null hypothesis has been accepted, and the alternative hypothesis will be rejected. Here it can be added that this result is not supporting the previous study done by Anvar \& Venter, (2014). that there was deference in information gender-wise and Female having the lead towards the information regarding green product packaging than male members. Moreover, it can be reviled that most of our respondents are highly educated. However, knowledge and information towards green product packaging are not favorable, and it shows there is a lack of campaign concerning the sustainable/ green environment in general and regarding the green product and packaging particularly. Therefore, marketers and stakeholders of environmental concern need to have a great call for the campaign to the sustainable environment and green product packaging. 
Table 4. Respondents opinion regarding the information sources about ecological/ organic product packaging

\begin{tabular}{lcllllll}
\hline Variables & Observed & $\begin{array}{l}\text { Valid } \\
\text { Percent }\end{array}$ & $\begin{array}{l}\text { Cumulative } \\
\text { Percent }\end{array}$ & Expected & Difference & $\begin{array}{l}\text { Difference } \\
\text { Sq. }\end{array}$ & $\begin{array}{l}\text { Diff. Sq. } \\
\text { / Exp Fr. }\end{array}$ \\
\hline $\begin{array}{l}\text { Directly from the } \\
\text { product label }\end{array}$ & 135 & 41.28 & 41.28 & 81.75 & 53.25 & 2835.56 & 34.69 \\
\hline $\begin{array}{l}\text { From the } \\
\text { information } \\
\text { campaigns of } \\
\text { producers and } \\
\text { merchants }\end{array}$ & 63 & 19.27 & 60.55 & 81.75 & -18.75 & 351.56 & 4.30 \\
\hline $\begin{array}{l}\text { From the internet } \\
\text { (social media, } \\
\text { websites, etc.) }\end{array}$ & 127 & 38.84 & 99.39 & 81.75 & 45.25 & 2047.56 & 25.05 \\
\hline Other Sources & 2 & & & & & & \\
\hline Total & 327 & 0.61 & 100.00 & 81.75 & -79.75 & 6360.06 & 77.80 \\
\hline
\end{tabular}

The $\mathrm{Chi}^{\wedge} 2$ goodness of fit test value is: 141.832 value is 141.832 . The $\mathrm{p}$-value is $<.00001$. The result is significant at $\mathrm{p}<.05$.

Source: author's calculations

From the Table 4 a total picture of information/ knowledge sources of consumer towards green products packaging can be revealed, majority of respondents were agreed that they are getting the information from the product label directly (41.28\%), followed by from the internet( Social media etc.) (38.84\%), from the information campaigns given by producers and merchants $(19.27 \%)$ and other sources were very insignificance $(0.61 \%)$ respectively. So, it can be express here that more than $80 \%$ of the respondents opined among the given sources two sources namely directly from the product level and from the internet were the most important sources regarding the green product packaging. Looking at the hypothesis (Ho3): There are no differences among consumers perception regarding the information sources of ecological (organic) product packaging. From the result of table 4; it is observed that the Chi-Squared calculated p-value is $<.00001$ that is smaller than the Alfa value $(0.05)$. Hence the null hypothesis will be rejected, and it can be stated that there are differences among the information sources within the consumers, and the alternative hypothesis will be accepted. Moreover, from the result, it is also noted that Ha4: Product labels are the most preferred source of information about ecological/organic product packaging, as observed from the result product labels as an information source having at the highest frequency (135/327 about 41.28\%) than the expected frequency $(81.75 / 327$ around 25\%) among the variables. Therefore, it will be stated that the alternative hypothesis product labels are the most preferred source of information about ecological/organic product packaging will be accepted and the result of this study also support the previous study too (Ketelsen et al., 2020; Sammer \& Wüstenhagen, 2006). From the result, it is suggested that the marketer of an eco-friendly product or the other stakeholders of environmental concerned should provide the product labels as a source of information for sustainable packaging at priority as shopper consider it as a very prominent source to convey the message regarding the product and its environmental benefit and secondly marketers can use the internet (social media, websites, etc.) to communicate as well as to attract the customer regarding eco-friendly product and its packaging benefits because these two sources are most noticeable elements and having the importance as a source of information among the consumers.

Table 5. Consumer preferences towards the factors of willingness to pay for the ecological/ organic

\begin{tabular}{llllllll}
\hline Factors & $\begin{array}{l}\text { Observed } \\
\text { Frequency }\end{array}$ & $\begin{array}{l}\text { Valid Cumulative } \\
\text { Percent Percent }\end{array}$ & Expected & Difference & $\begin{array}{l}\text { Difference } \\
\text { Sq. }\end{array}$ & $\begin{array}{l}\text { Diff. } \\
\text { Sq. / } \\
\text { Exp Fr. }\end{array}$ \\
\hline $\begin{array}{l}\text { I am not willing to } \\
\text { pay more }\end{array}$ & 51 & 12.44 & 12.44 & 82 & -31.00 & 961.00 & 11.72 \\
\hline I feel myself & 104 & 25.37 & 37.80 & 82 & 22.00 & 484.00 & 5.90 \\
\hline
\end{tabular}




\begin{tabular}{|c|c|c|c|c|c|c|c|}
\hline $\begin{array}{l}\text { involved in } \\
\text { environmental } \\
\text { protection }\end{array}$ & & & & & & & \\
\hline $\begin{array}{l}\text { In the long run, } \\
\text { the cost is lower } \\
\text { due to reuse }\end{array}$ & 102 & 24.88 & 62.68 & 82 & 20.00 & 400.00 & 4.88 \\
\hline $\begin{array}{l}\text { It has better } \\
\text { quality }\end{array}$ & 101 & 24.63 & 87.32 & 82 & 19.00 & 361.00 & 4.40 \\
\hline $\begin{array}{l}\text { It improves } \\
\text { product durability }\end{array}$ & 52 & 12.68 & 100.00 & 82 & -30.00 & 900.00 & 10.98 \\
\hline & 410 & 100.00 & & & & & 37.878 \\
\hline
\end{tabular}

The Chi^2 Goodness of Fit value is 37.878 . The $\mathrm{p}$-value is $<.00001$. The result is significant at $\mathrm{p}<.05$.

Source: author's calculations

As shown in table 5, consumer preferences towards the factors of willingness to pay for the ecological/ organic , it reveals that around $75 \%$ consumer prefer to pay for the green products due to the different aspects attached with it such as the first factor was they feel involved in the environmental protection $(25.37 \%)$ followed by In the long run the cost will be lower due to reuse $(25.88 \%)$. It has better quality $(24.63 \%)$ respectively. It is interesting to note that the factor; it improves product durability (12.68\%) and I am not willing to pay more for the eco-friendly product packaging (12.44\%) were preferred by the consumer. However, these two factors had very less representation among the other factors and even the probability of these factors are very insignificance among the tested factors. The Hypothesis (Ho5); There are no differences in the factors of willingness to pay for the ecological/ Organic has been tested and From the result of table 5; it can be observed in the Chi-Squared calculated the p-value is $<.00001$ that is smaller than the Alfa value (0.05), thus null hypothesis will be rejected. Alternative hypothesis will be accepted, and it can be stated that there are differences among the consumer opinion towards the factors of willingness to pay for the ecological/ organic product. From the result it is also revealed that when the consumer pays for a green product, they feel involved in environmental protection, they presume in the long-run cost of such product will be lower due to reuse. This type of product has better quality. This indicates the positive sign of stakeholders of environmental concern and the marketer of green product seller in general as consumers have positive attitudes towards green product purchase. In future, it will have an influential part of the organization who has a sustainable environmental concern.

Table 6. Respondents opinion regarding the factors of unwillingness to purchase of ecological/ organic packaging product

\begin{tabular}{|c|c|c|c|c|c|c|c|}
\hline Variables & $\begin{array}{l}\text { Observed } \\
\text { Frequency }\end{array}$ & Percent & $\begin{array}{l}\text { Cumulative } \\
\text { Percent }\end{array}$ & Expected & Difference & $\begin{array}{l}\text { Difference } \\
\text { Sq. }\end{array}$ & $\begin{array}{l}\text { Diff. } \\
\text { Sq. / } \\
\text { Exp Fr. }\end{array}$ \\
\hline $\begin{array}{l}\text { All of them are the main } \\
\text { reasons }\end{array}$ & 61 & 26.29 & 26.29 & 58 & 3.00 & 9.00 & 0.16 \\
\hline $\begin{array}{l}\text { Eco-packaging does not } \\
\text { bring any benefit }\end{array}$ & 28 & 12.07 & 38.36 & 58 & -30.00 & 900.00 & 15.52 \\
\hline $\begin{array}{l}\text { Lack of information towards } \\
\text { Eco-packaging product }\end{array}$ & 90 & 38.79 & 77.16 & 58 & 32.00 & 1024.00 & 17.66 \\
\hline Lack of purchasing power & 53 & 22.84 & 100.00 & 58 & -5.00 & 25.00 & 0.43 \\
\hline Total & 232 & 100 & & & & & 33.759 \\
\hline
\end{tabular}


Table 6 reveals a total image of the factors of unwillingness to purchase of ecological/ organic packaging product, majority of respondents were agreed that lack of information towards the eco-packaging product (38.79\%) was the main reason, followed all of the factors in this categories are the main reasons $(26.29 \%)$, lack of purchasing power (22.84\%), eco-packaging does not bring any benefit to the purchaser $(12.07 \%)$ respectively. It is an unambiguous indication that the majority among the respondents claim that lack of information towards the ecological/ green packaging product was the main reason for not to purchase the green packaging product. This result also supports the previous study (Ansar, 2013). From the result of table 6, it is noted that the Chi^2 value (Goodness of Fit) is 33.759, and the $\mathrm{p}$-value is $<.00001$. Hence the result is significant at $\mathrm{p}<.05$. Value and the null hypothesis (Ho6); There are no differences among the factors of unwillingness to purchase for the ecological/ organic packaging product will be rejected, and the alternative hypothesis will be accepted.

Consequently, it can be stated that there are differences among the factors of unwillingness to purchase for the ecological/ organic packaging product among the consumers. When analyzed the one more alternative Hypothesis (Ha7); Lack of information was the main reason among the factors in the unwillingness to purchase for the ecological/ organic packaging product in this study. It is to be noted that the alternative hypothesis lack of information are the main factors in the unwillingness to purchase for the ecological/ organic packaging product has been accepted as there are very positive differences between observed frequency and expected frequency and this has also been pointed out by the majority of the consumers. It is interesting to note that this study also supports the previous study (Ansar, 2013). Moreover, it is suggested that the marketer of the eco-friendly product its related stakeholders should inform as much as they can their best through the different mode of preferred information sources such as information from the product labels as this source of information has priority among them. Secondly, marketers can use the internet (social media, websites, etc.) to communicate as well as to attract the customer regarding eco-friendly product and its packaging benefits, with another suitable campaign.

Table 7. Consumer attitudes towards consideration of quality certification (stamp) on the packaging before the purchase of an organic product such as The Saudi standards metrology and quality organization (SASO) / Saudi food and drug authority (SFDA)

\begin{tabular}{llllllll}
\hline Scale/ Freq & $\begin{array}{l}\text { Observed } \\
\text { Frequency }\end{array}$ & $\begin{array}{l}\text { Per } \\
\text { cent }\end{array}$ & $\begin{array}{l}\text { Cumulative } \\
\text { Percent }\end{array}$ & $\begin{array}{l}\text { Expected } \\
\text { Frequency }\end{array}$ & Difference & $\begin{array}{l}\text { Difference } \\
\text { Sq. }\end{array}$ & $\begin{array}{l}\text { Diff. Sq. / } \\
\text { Exp Fr. }\end{array}$ \\
\hline Always & 71 & 30.603 & 30.603 & 46.4 & 24.60 & 605.16 & 13.04 \\
\hline Most of the time & 49 & 21.121 & 51.724 & 46.4 & 2.60 & 6.76 & 0.15 \\
\hline Sometimes & 63 & 27.155 & 78.880 & 46.4 & 16.60 & 275.56 & 5.94 \\
\hline Rarely & 36 & 15.517 & 94.397 & 46.4 & -10.40 & 108.16 & 2.33 \\
\hline Never & 13 & 5.603 & 100.000 & 46.4 & -33.40 & 1115.56 & 24.04 \\
\hline Total & 232 & 100 & & \\
\hline \multicolumn{7}{l}{ The Chi^2 $^{\wedge}$ goodness of fit test value is 45.5. The p-value is < .00001. The result is significant at $\mathrm{p}<.05}$. \\
\hline
\end{tabular}

Source: author's calculations

Table 7 shows the results of consumer attitude towards consideration of quality certification (stamp) on the packaging before the purchase of an organic product such as The Saudi standards metrology and quality Organization (SASO) / Saudi food and drug authority (SFDA), as it was a one objectives of this study. From the table, it can be determined that more than $79 \%$ of the consumer do consider towards the quality certification (stamp) on the packaging before the purchase of an organic product such as The Saudi standards metrology and quality Organization (SASO) / Saudi food and drug authority (SFDA) except rarely considered (15.52\%). The opinion went to never considered $(5.063 \%)$. From the outcome, it is revealed that when the consumer is more concern toward the quality certification stamps from the quality certifications organization, either it is by the government or it is from any third party. Therefore, such organization who deals with the sustainable products it should be mandatory to have quality certification stamp to the eco-friendly product. This stamp or certifications will lead to the marketer as a value addition to their brand or products, and it will be highly acceptable by the consumers. Besides, this will give an excellent image to the company who has the certification of quality standard in the eyes of the shopper as well as the related stakeholders that are concerned to the sustainable environment. From the result of table 7, a suggestive hypothesis can be revealed that the $\mathrm{Chi}^{\wedge} 2$ value (Goodness of Fit) is 45.5 , and the p-value is $<.00001$. Hence the 
result is significant at $\mathrm{p}<.05$. Value and a hypothesis can be suggested that there is the difference in opinion towards the consideration of quality certification (stamp) on the packaging before the purchase of an organic product such as The Saudi standards metrology and quality organization (SASO) / Saudi food and drug authority (SFDA).

Table 8. Views of the respondents regarding the responsibility towards sustainable environment mainly green product

\begin{tabular}{llllllll}
\hline Categories & $\begin{array}{l}\text { Observed } \\
\text { Freq }\end{array}$ & $\begin{array}{l}\text { Valid } \\
\text { Percent }\end{array}$ & $\begin{array}{l}\text { Cumulative } \\
\text { Percent }\end{array}$ & Expected & Difference & $\begin{array}{l}\text { Difference } \\
\text { Sq. }\end{array}$ & $\begin{array}{l}\text { Diff. } \\
\text { Sq. / } \\
\text { Exp Fr. }\end{array}$ \\
\hline Consumer himself & 80 & 17.98 & 17.98 & 111.25 & -31.25 & 976.56 & 8.78 \\
\hline $\begin{array}{l}\text { Ministry of } \\
\text { Environment, }\end{array}$ & 171 & 38.43 & 56.40 & 111.25 & 59.75 & 3570.06 & 32.09 \\
$\begin{array}{l}\text { Water, and } \\
\text { Forestry }\end{array}$ & & & & & & & \\
\hline $\begin{array}{l}\text { Nongovernmental } \\
\text { organizations }\end{array}$ & 67 & 15.06 & 71.46 & 111.25 & -44.25 & 1958.06 & 17.60 \\
\hline $\begin{array}{l}\text { Producers and } \\
\text { traders }\end{array}$ & 127 & 28.54 & 100.00 & 111.25 & 15.75 & 248.06 & 2.23 \\
\hline & & & & & & & \\
\hline
\end{tabular}

Source: author's calculations

The results, as reflected in Table 8, views of the respondents regarding the responsibility towards sustainable environment mainly green product. It indicates that majority of the respondents (38.48\%) opined that .responsibility towards sustainable environment mainly green product goes to the ministry of environment, water, and forestry is to vigorously implement the policy towards the sustainable environments followed by producers and traders (28.54\%), consumer himself $(17.98 \%)$ and nongovernmental organizations (NGOs) $(15.06 \%)$ respectively. From the result of $\mathrm{Chi}^{\wedge} 2$ Goodness of Fit,) value 60.699 and the $\mathrm{p}$-value is $<.00001$. Therefore, it can also be noticed that suggestive null hypothesis will be rejected and a suggestive alternative hypothesis can be revealed in term of that there is deference in views of respondents regarding the responsibility towards a sustainable environment, mainly green product. Hence, the significant responsibilities towards the sustainable environment in general and particularly for green products packaging felt by consumers that the ministry of environment, water, and forestry should make the policy related to this. The producers and traders should strictly follow the policy made by government officials. Also, the consumer should be responsible for a sustainable environment, and NGOs could lead to promote and campaign to maintain a green environment. Here it should also be noted that the government can utilize the NGOs services to promote an eco- friendly environment within the society. Hence this will help to minimize the environmental disaster and global warming as these are a significant concern nowadays.

\section{Conclusion}

This study sought to investigate the impact of sustainable product packaging on the purchasing behavior of Saudi Arabian consumers. Majority of respondents were male among the respondents a big number of respondents represents to the young age group with good academic profile those having monthly income between the income group of $5000 \mathrm{SR}$ to $25000 \mathrm{SR}$. There are no differences in the opinion among the consumer towards sufficient knowledge/ information on the green product packaging. Here it is noted that this result supports the studies done past (Arseculeratne \& Yazdanifard, 2014; Golkonda, 2013) and (Golkonda, 2013) and it indicates that there are no differences in opinion gender-wise (Ho1). Male consumers having the lead towards the information regarding green product packaging than female members in this study hereafter hypothesis $(\mathrm{Ha} 2)$ has been rejected, and it is pointed out that this result does not support the previous study (Anvar \& Venter, 2014). However, it is observed that knowledge and information towards green product packaging are not favorable, and it shows there is a lack of campaign concerning to the sustainable/ green environment in general and particularly regarding the green product packaging. So, it is advised that, marketers and stakeholders of environmental concerned need to have a great call for the campaign to the sustainable environment and green product packaging. 
Majority of respondents are getting the information from the product label directly followed by from the internet (Social media, company websites, etc.) Highest majority of the respondents opined among the two sources of information namely directly from the product label and from the internet are the most important sources of information about the green product packaging. In addition, it can be stated that there are differences among the information sources within the consumers (null hypothesis Ho3 has been rejected), and it is reveals that product labels are the most preferred source of information about ecological/organic product packaging. Moreover, product labels are the most preferred source of information about ecological/organic product packaging (the alternative hypothesis; Ha4) are accepted as the result of this study also support the previous study too (Ketelsen et al., 2020; Sammer \& Wüstenhagen, 2006). Here, it is suggested that the marketer of an eco-friendly product or the other stakeholders of environmental concerned should provide the product labels as a source of information for sustainable packaging at priority level as shopper consider it as a very prominent source to take the message regarding the green product. Secondly marketers can use the internet (social media, websites, etc.) to communicate as well as to attract the customer regarding eco-friendly product and towards green product packaging because these two sources are most noticeable elements and having the importance as a source of information among the consumers.

A big percentage of consumers prefer to pay for the green products due to the different aspects attached with it such as the first factor was they feel involved in the environmental protection followed by in the long run the cost will be lower due to re-use, and it has better quality respectively. The Hypothesis (Ho5); There are no differences in the factors of willingness to pay for the ecological/ has been rejected. In this result it is also revealed that when the consumer pays for a green product, they feel involved in environmental protection, they presume in the long-run cost of such product will be lower due to reuse and this type of product has better quality. This indicates the positive sign of stakeholders of environmental concern and the marketer of green product seller in general as consumers have positive attitudes towards green product purchase. In future, it will have an influential part of the organization who has a sustainable environmental concern. In addition, regarding the factors of unwillingness to purchase of ecological/ organic packaging product, lack of information towards the eco-packaging product are the main reason and this result supports the previous study by Ansar, (2013) too. The null hypothesis (Ho6); There are no differences among the factors of unwillingness to purchase for the ecological/ organic packaging product has been rejected, and the alternative hypothesis will be accepted. Consequently, it can be stated that there are differences among the factors of unwillingness to purchase for the ecological/ organic packaging product among the consumers.

When analyzed the alternative Hypothesis (Ha7); It is to be noted that the alternative hypothesis lack of information are the main factors in the unwillingness to purchase for the ecological/ organic packaging product has been accepted this study also supports the previous study done by the researcher (Ansar, 2013). Moreover, it is suggested that the marketer of the eco-friendly product its related stakeholders should inform as much as they can their best through the different mode of preferred sources information such as information from the product labels has first priority as an information source of green product packaging among them. Secondly, marketers can use the internet (social media, websites, etc.) to communicate as well as to attract the customer regarding eco-friendly product and its packaging benefits, with another suitable campaign. To know the consumer attitude towards consideration of quality certification (stamp) on the packaging before the purchase of an organic product such as The Saudi standards metrology and quality organization (SASO)/ Saudi food and drug authority (SFDA) stamp, was a one objectives of this study and it is revealed that majority approximately $80 \%$ of the consumer do consider the quality certification (stamp) on the packaging before the purchase of an organic product. Here is seen that the consumer is more concern toward the quality certification stamps from the quality certifications organization, either it is by the government or it is from any third party such organization. The organization who deals with the sustainable products they should make mandatory to have quality certification stamp to the eco-friendly product. This stamp or certifications will lead to the marketer as a value addition to their brand or products, and it will be highly acceptable by the consumers. Besides, this will give an excellent image to the company who has the certification of quality standard in the eyes of the shopper as well as the related stakeholders that are concerned to the sustainable environment.

From this result (Table 7) a suggestive hypothesis has been discovered that there is the difference in opinion towards the consideration of quality certification (stamp) on the packaging before the purchase of an organic product such as The Saudi standards metrology and quality organization (SASO) / Saudi food and drug authority (SFDA) certification and stamp. Regarding the responsibility towards sustainable environment, mainly for green product goes to the ministry of environment, water, and forestry is to vigorously implement the policy towards the sustainable environments were given as a primary responsibility followed by producers \& traders, consumer himself and finally to the nongovernmental organizations (NGOs). Hence, here is suggested that the significant responsibilities towards the sustainable environment in general and particularly for green products packaging ministry of environment, water, 
and forestry should make the policy related to it. The producers and traders should strictly follow the policy that has been made by government officials. Correspondingly, the consumer should be responsible for a sustainable environment, and NGOs could lead to promote and campaign to maintain a green environment. Here it is recommended that the government can utilize the NGOs services to promote an eco- friendly environment within the society and this will help to minimize the environmental disaster and global warming as these are a significant concern nowadays.

\section{References}

Alam, M. Z. (2020). Children's predilections concerning the fast- foods/junk- foods in Saudi Arabia. International Journal on Emerging Technologies, 11(1), 108-113.

Ansar, N. (2013). Impact of Green Marketing on Consumer Purchase Intention. Mediterranean Journal of Social Sciences (online), 4(11), 650-655.

Anvar, M., \& Venter, M. (2014). Attitudes and Purchase Behavior of Green Products among Generation Y Consumers in South Africa. Medditerranean Journal of Social Sciences (online), 5(21), 183-194.

Arseculeratne, D., \& Yazdanifard, R. (2014). How green marketing can create a sustainable competitive advantage for a business. International Business Research, 7(1), 130-137.

Boztepe, A. (2012). Green marketing and Its Impact on Consumer Buying Behavior. European Journal of Economic and Political Studies (online), 5(1), 5-19.

Brundtland, G. H. (1987). Our common future - call for action. Environmental Conservation, 14(4), 291-294.

Bukhari, S. S. (2011). Green Marketing and its Impact on Consumer Behavior. European Journal of Business and Management (online), 3(4), 375-383.

Burrow, J. L. (2008). Marketing (2nd ed.). Ohio: Thomson South-Western.

Carlson, K. (2009). Green Your Work. Adam Business: Avon, MA, USA.

Chen, Y. (2010). The drivers of green brand equity: Green brand image, green satisfaction and green trust. Journal of Business Ethics, 93(2), 307-319. https://doi.org/10.1007/s10551-009-0223-9

Diglel, A., \& Yazdanifard, R. (2014). Green marketing and its Influence on Buying Behavior and the Attitudes of Purchasers towards Eco-friendly products. Global journal of Management and Business Research (online), 7(11), 11-18.

Draskovic, N., Temperley, J., \& Pavicic, J. (2009). Comparative perception of consumer goods packaging: Croatian consumers perspective. Int. J. Manag. Cases, 11, 154-163.

Fatah Uddin, S. M., \& Mohammed Naved, K. (2018). Young Consumer's Green Purchasing Behavior: Opportunities for Green Marketing. Journal of Global Marketing, 31(4), 270-281.

Golkonda, S. B. (2013). Bioproducts: Consumers' perception and buying behavior. Tennessee State University, ProQuest Dissertations Publishing, 1548023.

Kaufmann, H. R., Panni, M. F. A. K., \& Orphanidou, Y. (2012). Factors affecting consumers' green purchasing behaviour: an integrated conceptual framework. Amfiteatru Economic, 15(31) 50-69.

Ketelsen, M., Janssen, M., \& Hamm, U. (2020). Consumers' Response to Environmentally- friendly Food Packaging: A Systematic Review. Journal of Cleaner Production, 254, 120-123 https://doi.org/10.1016/j.jclepro.2020.120123

Lamb, C. W., Hair, J. F., \& McDaniel, C. (2011). Essentials of Marketing: A Marketing Strategy Planning Approach. McGraw-Hill/Irwin: New York, NY, USA.

Mainieri, T., Barnett, E. G., Valdero, T. R., Unipan, J. B., \& Oskamp, S. (2010). Green Buying: The Influence of Environmental Concern on Consumer Behavior. The Journal of Social Psychology, 137(2), 189-204. https://doi.org/10.1080/00224549709595430

Pedersen, E., \& Neergaard, P. (2006). Caveat emptor - let the buyer beware! Environmental labelling and the limitations of 'green' consumerism. Business Strategy \& the Environment, 15(1), 15-29. https://doi.org/10.1002/bse.434

Polonsky, J. M. (1994). An introduction to green marketing. Electronic Green Journal, 1(2), 1-10. 
Purohit, H. C. (2012). Product positioning and consumer attitude towards eco-friendly labeling and advertisement: An analytical study. Journal of Management Research, 12(3), 153-162.

Rashid, N. R. N. A. (2009). Awareness of eco-label in Malaysia's green marketing initiative. International Journal of Business and Management, 4(8). Retrieved from http://www.ccsenet.org/journal/index.php/ijbm/article/view/3376/3039

Rayapura, A. (2014). New Nielsen Study Says Consumers Are Ready to Pay More for Social Responsibility.

Retrieved from http://www.alriyadhdaily.com/article/e094bc6f052f47de859d5c87170dda0

Retrieved from http://www.sustainablebrands.com/newsandviews/stakeholder_trends_insights/aarthi_rayapura/new_nielsen_stu dy_says_consumers_are_ready

Retrieved from https://www.arabnews.com/node/1528436/saudi-arabia

Retrieved from https://www.businesswire.com/news/home/20191106005961/en/Saudi-

Retrieved from https://www.businesswire.com/news/home/20191106005961/en/Saudi-Arabia-Plastic-Packaging-Market-Growt h-Trends

Retrieved from https://www.unicef.org/about/execboard/files/Saudi_Arabia_-_UNCCSF_2017-2021.pdf

Sammer, K., \& Wüstenhagen, R. (2006). The influence of eco-labeling on consumer behavior - results of a discrete choice analysis for washing machines. Business Strategy \& the Environment, 15(3), 185-199. https://doi.org/10.1002/bse.522

Stern, N. Z., \& Ander, W. N. (2008). Greentailing and other revolutions in retail. Hot ideas that are grabbing customers' attention and raising profits. Hoboken, N.J: Wiley.

Suki, N. M. (2013). Green Awareness effects on consumer's purchasing decision: Some insights from Malaysia. Green Awareness Effect, 9, 50-63.

Yazdanifard, R., \& Mercy, I. E. (2011). The impact of green marketing on customer satisfaction and environmental safety. International Conference on Computer Communication and Management, 5, 637-641.

Yeow, K. Y., \& Rashad, Y. (2014). The concept of green marketing and green product development on consumer buying approach. Global Journal of Management and Commerce Perspectives, 3(2), 33-38.

\section{Copyrights}

Copyright for this article is retained by the author(s), with first publication rights granted to the journal.

This is an open-access article distributed under the terms and conditions of the Creative Commons Attribution license (http://creativecommons.org/licenses/by/4.0/). 